\title{
CSR Reporting Practices of Hungarian Banks
}

\author{
D. D. HORVÁTH
}

University of Miskolc, Faculty of Economics, Institute of Management Science, szvhdora@uni-miskolc.hu

Abstract. The disclosure of information on the exercise of corporate social responsibility (CSR) is the tool most frequently used by companies to promote understanding of the social and environmental performance of an organisation and to improve relationships with stakeholders. For most of the world's largest companies, reporting on non-financial information appears to be a continuing trend, so it is essential to present the new corporate reporting trends of the 21st century. The disclosure of socially responsible information will be analysed, with a focus on the application of the Global Reporting Initiative guidelines related to CSR. Global Reporting Initiative (GRI) is the best-known framework for voluntary reporting of environmental and social performance by business worldwide. The main objective of the paper is to explore the corporate voluntary disclosure practices of the listed and non-listed banks in Hungary. The extent of voluntary disclosure has significantly improved for decades worldwide, but the situation is not that obvious regarding the Hungarian financial sector. This paper aims to describe the status of disclosure practices of corporate sustainability in the annual reports, sustainability reports or CSR reports of the banking industry in Hungary. Also, increased corporate visibility and financial risk increase stakeholder demand for transparency on the social impact of financial institutions and their CSR practices. Finally, the analysis and subsequent comparison of available CSR reports of banks will be presented.

\section{Introduction}

A considerable amount of literature has been published on CSR. The first serious discussions of that topic emerged during the 1950s, when Bowen [6] introduced the idea of social responsibility of a businessman in a wider sphere than pure profit seeking. [5]

More recently, the importance of CSR behaviour of companies and the need for CSR reporting turned up as an answer to corporate scandals, concern about labour rights, product safety, poverty reduction, financial crises, climate change, etc. [13] It has become a necessary tool to reach sustainable development and should mean more for decision-makers than just an effective public relations tool used by a company to increase corporate profitability. [16]

Corporate social responsibility (CSR) is a very broad concept which includes different dimensions. The central idea of the concept arises from the argument that a company must have other objectives in addition to maximizing profit. The implementation of this idea has several levels. [1]

Carroll (1991) divides the concept of CSR into four different categories as economic, legal, ethical and discretionary, describing them as the levels of a pyramid (Figure 1). The highest level includes a proactive approach in which companies take social initiatives. On the other hand the minimum level of 
the concept requires the company behave ethically, business ethics can be placed as a core element in the discussion of CSR. [8]

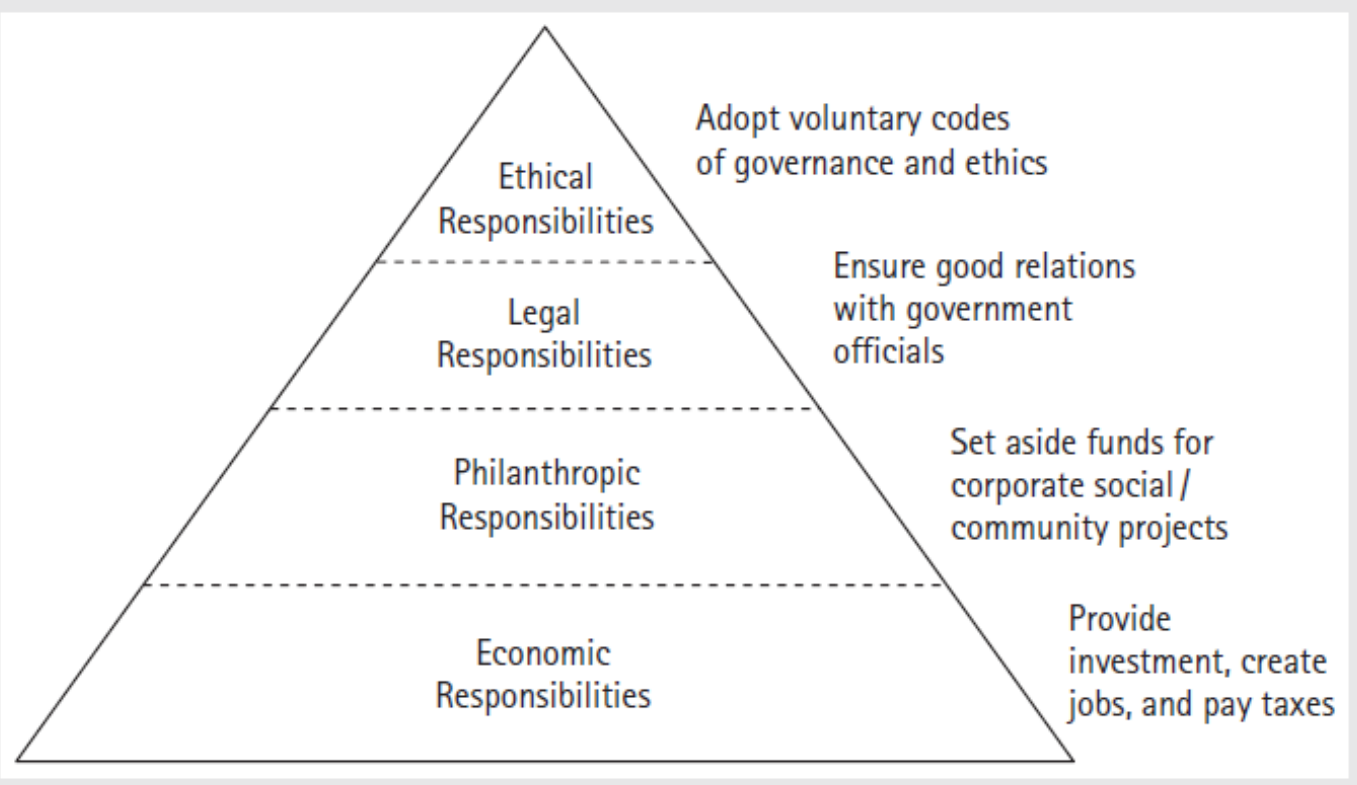

Figure 1. Carroll's CSR Pyramid

(Source: [8])

\section{CSR reporting}

For most of the world's largest companies, reporting on non-financial information appears to be an ongoing trend. Communication of social and environmental dimensions of the company plays a key role in the sustainable development of organizations.

We are currently witnessing a shift from traditional reporting models that focus mostly on financial and historical data to new forms of reporting, which adopt the triple bottom line approach and thus also include corporate social responsibility disclosure. Triple bottom line reporting (Figure 2) refers to corporate sustainability reporting, which includes non-financial key performance indicators (such as environmental and social indicators). Therefore, it is dedicated to a broader set of stakeholders than shareholders. [4] 


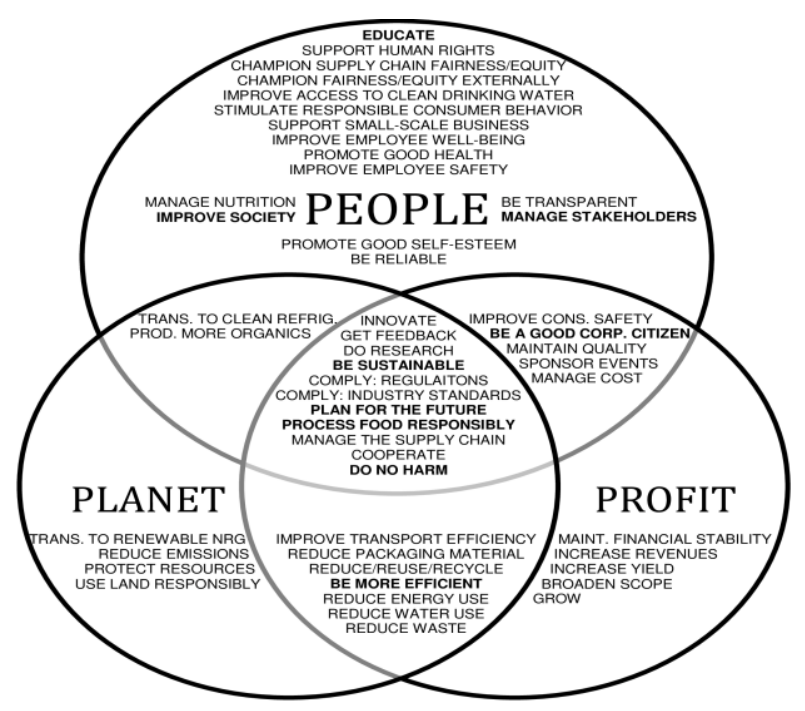

Figure 2. Triple bottom line approach

(Source: [4])

Companies have recently struggled with increased pressure from internal and external stakeholders to report not only on financial but also on their social and environmental performance.

Hence, examining the reasons and methods of companies' corporate social responsibility (CSR) reporting appears a promising field for researchers, and sustainability reporting becomes the subject of increased attention from both the business and the academic community.

Providing CSR reports is voluntary in most cases, but in some countries there are regulations making disclosure on CSR mandatory. Governments and stock exchanges play a significant role in promoting the non-financial reporting as they are responsible for issuing relevant legislation and standards concerning the mandatory disclosures on CSR issues. [13] In Europe, there are already some regulations regarding the CSR disclosure in countries such as the United Kingdom, Germany, France, Switzerland, Norway, Sweden, Finland and Denmark.

There can be several reasons why a company reports on its non-financial activities. The most important motives are as follows:

- To display its responsibility towards a wide range of stakeholders;

- To respond to stakeholders' expectations and contribute to society well-being;

- To manage their own legitimacy;

- To guard a company's reputation and identity by engaging with stakeholders;

- Long-term profitability by reducing information asymmetries and improving stakeholder decision making;

- To diverse institutional pressure. [5]

Some of the most significant and valid standards and regulations can be listed as follows:

ISO 14000 Environment Management Standards 
Set of these standards are aimed to decrease the use of natural resources, minimize the harmful effects on soil, water and air. ISO 14000 standards are based on monitoring and improvement of environmental performances and enforce the corporations to comply with the regulations and standards set out by different authorities.

\section{SA 8000 Standards}

Social Accountability Organization is a non-profit organization sited in New York. It is mainly interested in improving working conditions, monitoring and securing the application of labor standards in all working environments.

\section{AccountAbility 1000 (AA 1000)}

In order to facilitate the responsibility understanding in sustainable development AccountAbility Organization introduced the AA1000 standards to the system in 1999. The major goals of these standards might be stated as to increase the professional approaches about establishment, social auditing and reporting activities of corporations. In this regard AccountAbility organization struggles in order to aggregate accounting, auditing related standards and ethical issues in accountability. Within this context, organization developed a general framework about securing and rating the applications.

\section{United Nations Global Compact}

United Nations Global Compact (UNGC) was initiated in 2000 and it aims to make policies and implement them within the context of sustainability and corporate social responsibility. UNGC is not only aimed to comprise United Nations members, it also aims to regulate and embrace every governmental and non-governmental organization and private corporation. [2]

\section{GRI}

Global Reporting Initiative (GRI) guidelines were founded in 1997 by the Coalition for Environmentally Responsible Economies (CERES) and the United Nations Environmental Programme (UNEP) and has been developed through multi-stakeholder engagement. [4] [12] GRI reports currently approach about forty percent of all corporate responsibility reports worldwide and according to results reported by Welford (2004) and Rowe (2006), Europe has the highest number of GRI certifications. [15][18]

Outtes-Wanderley, Soares, Lucian, Farache, and de Sousa Filho Milton (2008) emphasized that the reason behind this could be that developed nations such as Eurozone countries implement practical actions that stimulate CSR development. [14]

GRI disclosure is based on the triple bottom line approach including three sets of indicators, namely economic, environmental and social factors. Even though GRI reporting has spread around the world, there is still criticism relating to the large number of indicators proposed (84 indicators), and the fact that preparing the report in accordance with GRI standards is quite expensive for companies, which might be the reason for the ongoing reluctance of some companies to adopt this framework. The GRI's 
mission is to improve the quality, rigour and relevance of sustainability reports so that they reach a level equivalent to financial statements. [10]

\section{Reporting practices in the world}

KPMG, a global network of professional firms providing Audit, Tax and Advisory services, provides regular survey of CSR reporting since 1993. Since then, the ratio of companies with CSR reports has been increasing. KPMG's surveys of CSR reporting started with $12 \%$ and after 20 years it has arisen to $71 \%$. Growth in percentage of companies with CSR report is very positive. It may be assumed that with the increasing importance of CSR, percentage of CSR reporting will also increase. [11]

The survey of 2013 covered 100 largest companies in 41 countries. To compare, the survey provided in 2011 looked at 100 largest companies in 34 countries.

The survey is based on a detailed study of company reporting on CSR performance, carried out by KPMG member firms' professionals. It is based on publicly available information in annual financial reports, CSR reports and on company websites.

The research includes reporting under terms sustainability (43\%), corporate social responsibility (25\%), corporate responsibility (14\%), sustainable development (6\%), corporate citizenship (2\%), environmental and social report (2\%), people-planet-profit (1\%), corporate responsibility \& sustainability (1\%) and other terms (6\%). The 100 largest companies from every country include publicly-listed companies and companies with different ownership structures such as privately-owned and state-owned businesses.

Countries included in KPMG's surveys of CSR reporting 2013 are as follows:

- Americas: Brazil, Canada, Chile, Colombia, Mexico, United States;

- Europe: Belgium, Denmark, Finland, France, Germany, Greece, Hungary, Italy, Netherlands, Norway, Poland,

- Portugal, Romania, Russia, Slovakia, Spain, Sweden, Switzerland, United Kingdom;

- Asia Pacific: Australia, China \& Hong Kong, India, Indonesia, Japan, Kazakhstan, Malaysia, New Zealand,

- Singapore, South Korea, Taiwan;

- Middle East \& Africa: Angola, Israel, Nigeria, South Africa, United Arab Emirates. [11] [17]

\section{Current state of CSR reporting in the EU}

In the GRI database, according to the date of April 2016, totally 33,072 CSR reports belonging to 9,047 organizations have been provided. European Union countries have filed 12,562 reports, and their structure is presented in Table 1 and Figure 3. It can be seen that Spain, Germany and the United Kingdom provided the largest amount of disclosures while Malta, Cyprus and Lithuania have hardly provided any reports. 
Surprisingly, Hungary takes place exactly in the middle of the list (14th of 28 countries), with 263 sustainability reports. We can notice some similarities among the countries with few disclosures such as the countries joined the European Union later had a direct impact on their CSR reporting practices. In these areas CSR reporting started about 2007 while the founding members (e.g. the United Kingdom and Germany) have been providing disclosures since 1999.

The new EU member states have two reasons for increasing their CSR reporting. First of all, they understand the importance and the impact of CSR in the community, and at the same time they have to obey the rules of EU Community. [3]

\begin{tabular}{|c|c|c|c|c|c|}
\hline No. & Country & $\begin{array}{c}\text { Number } \\
\text { of } \\
\text { reports }\end{array}$ & No. & Country & $\begin{array}{c}\text { Number } \\
\text { of } \\
\text { reports }\end{array}$ \\
\hline 1 & Austria & 513 & 15 & Italy & 736 \\
\hline 2 & Belgium & 367 & 16 & Latvia & 20 \\
\hline 3 & Bulgaria & 17 & 17 & Lithuania & 9 \\
\hline 5 & Croatia & 71 & 18 & Luxembourg & 60 \\
\hline 5 & Cyprus & 2 & 19 & Malta & 0 \\
\hline 6 & Republic & 90 & 20 & Netherlands & 939 \\
\hline 7 & Denmark & 326 & 21 & Poland & 169 \\
\hline 8 & Estonia & 9 & 22 & Portugal & 401 \\
\hline 9 & Finland & 711 & 23 & Romania & 48 \\
\hline 10 & France & 696 & 24 & Slovakia & 49 \\
\hline 11 & Germany & 1083 & 25 & Slovenia & 26 \\
\hline 12 & Greece & 335 & 26 & Spain & 1809 \\
\hline 13 & Hungary & 263 & 27 & Sweden & 947 \\
\hline Total number of reports & & United & 1189 \\
\hline
\end{tabular}

Table 1. Number of CSR reports

(Source: made by the author according to [3]) 


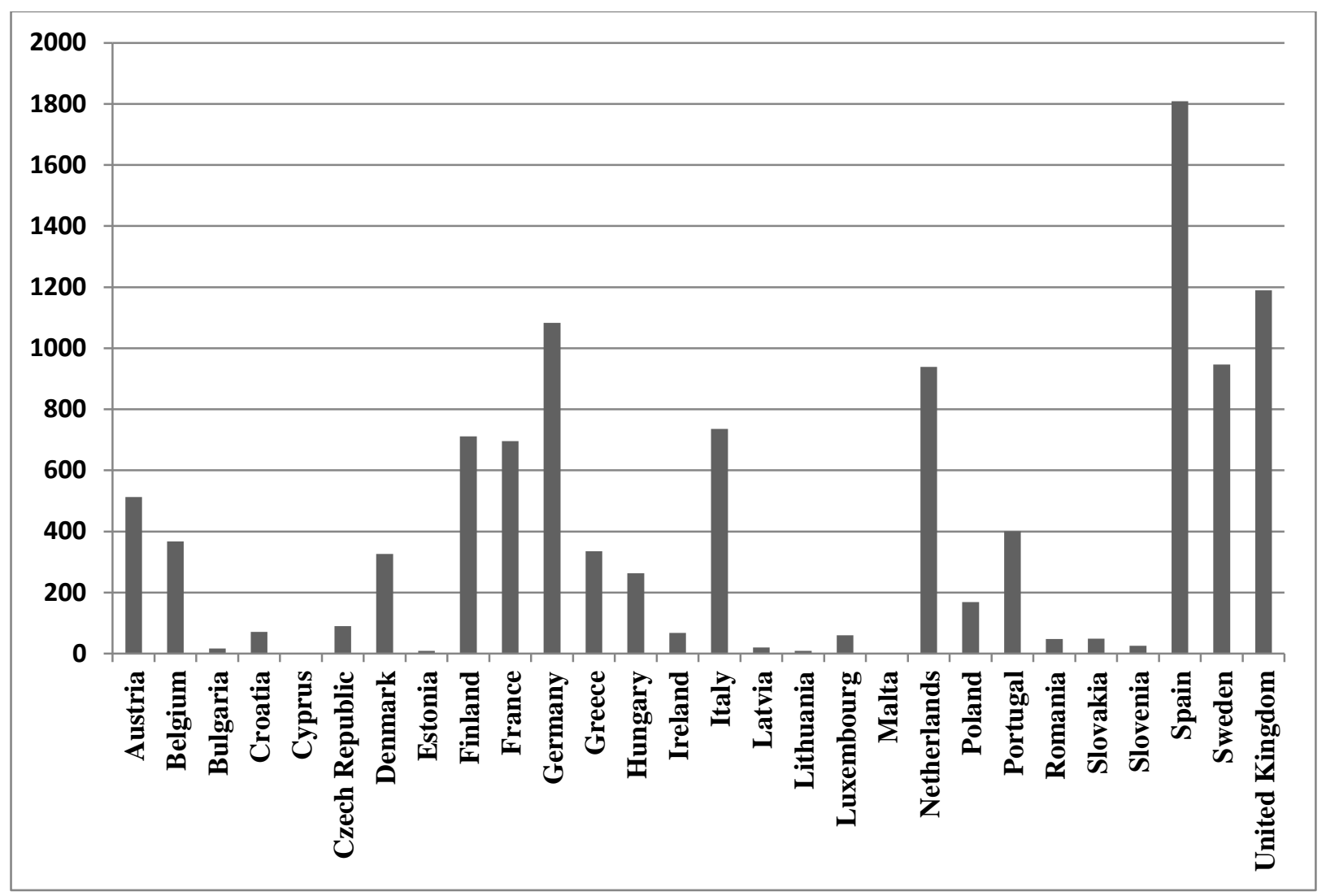

Figure 3. Number of CSR reports

(Source: made by the author according to [3])

In Figure 3 the structure of the reports are presented, based on the activity sectors. The companies belong to all 37 activity sectors, which represents $38 \%$ of the total reports filed with the GRI. The reporting period was between 1999 and 2016.

By analyzing the situation of the activity sectors of the companies that file CSR reports, we can see that most of them belong to companies from the financial service, food and beverage service and energy sectors (Table 2 and Figure 4). [3]

\begin{tabular}{|c|c|c|c|c|c|}
\hline No. & Organization Sectors & $\begin{array}{c}\text { Number } \\
\text { of reports }\end{array}$ & No. & Organization Sectors & $\begin{array}{c}\text { Number of } \\
\text { reports }\end{array}$ \\
\hline 1 & Agriculture & 72 & 20 & Logistics & 282 \\
\hline 2 & Automotive & 279 & 21 & Media & 235 \\
\hline 3 & Aviation & 244 & 22 & Metals Products & 278 \\
\hline 4 & Chemicals & 298 & 23 & Mining & 197 \\
\hline 5 & Commercial Services & 358 & 24 & Non-Profit/Services & 428 \\
\hline
\end{tabular}




\begin{tabular}{|c|c|c|c|c|c|}
\hline 6 & Computers & 50 & 25 & Public Agency & 225 \\
\hline 7 & Conglomerates & 298 & 26 & Railroad & 121 \\
\hline 8 & Construction & 448 & 27 & Real Estate & 344 \\
\hline 9 & Construction Materials & 319 & 28 & Retailers & 387 \\
\hline 10 & Consumer Durables & 94 & 29 & $\begin{array}{l}\text { Technology } \\
\text { Hardware }\end{array}$ & 154 \\
\hline 11 & Energy & 817 & 30 & Telecommunications & 477 \\
\hline 12 & Energy Utilities & 577 & 31 & Textiles and Apparel & 153 \\
\hline 13 & Equipment & 218 & 32 & Tobacco & 33 \\
\hline 14 & Financial Services & 1736 & 33 & Tourism/Leisure & 265 \\
\hline 15 & Food and Beverage Products & 845 & 34 & Toys & 8 \\
\hline 16 & Forest and Paper Products & 248 & 35 & Universities & 93 \\
\hline 17 & Health Care Products & 305 & 36 & Waste Management & 220 \\
\hline 18 & Health Care Services & 112 & 37 & Water Utilities & 165 \\
\hline 19 & $\begin{array}{l}\text { Household and Personal } \\
\text { Products }\end{array}$ & 147 & 38 & Other & 1041 \\
\hline \multicolumn{5}{|c|}{ Total } & 12571 \\
\hline
\end{tabular}

Table 2. Number of reports in organization sectors

(Source: made by the author according to [3])

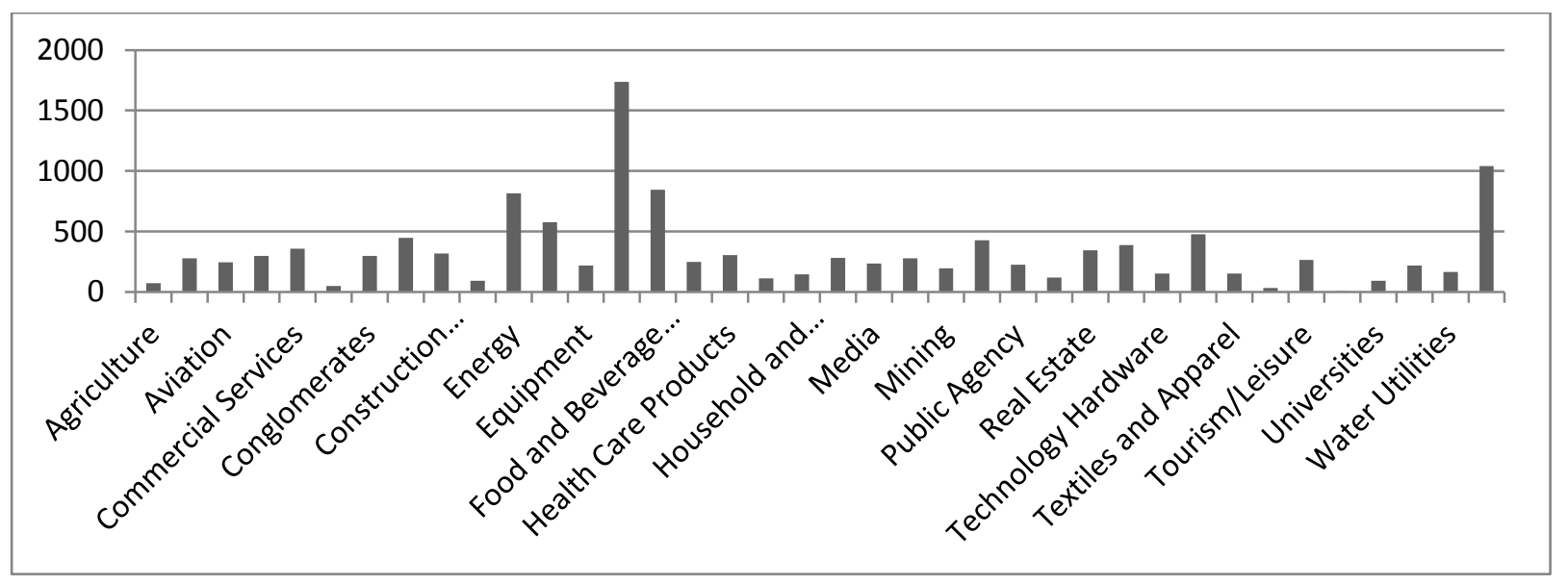

Figure 4. Number of reports in organization sectors

(Source: made by the author according to [3]) 


\section{Role of the financial sector regarding reporting practices}

The financial sector has meant a great hope of the GRI founders as a potential user of data on sustainability performance from the beginning. This hope has been realized to some extent by the socially responsible investment community (SRI) which, however, represents only a few percent of all investment funds. It seems that the mainstream institutional investors have shown little interest in the non-financial performance data so far.

There are many platforms regarding how banks disclose social responsibility information such as the Internet and annual reports.

Banking sector has two significant qualities in comparison with other sectors: the number of major stakeholders is larger in the banking sector and financial institutions are subject to heavier regulation. Major stakeholders of banks can be identified as owners, borrowers, depositors, regulators and managers. Along with shareholders and managers, depositors and regulators have a direct stake in bank performance. Banking sector can be considered as both a high-street presence and a high public visibility sector. [7]

The banking industry is an example of an industry which provides goods and services of a necessary nature, and whose business policies and practices are tied to the public interest. When organizations provide goods and services that are considered necessities by the general public, traditional business decisions about such issues as their availability, affordability, and safety move into the public arena.

Another important aspect to consider is that the attention some of these goods and services attract is related to the belief that consumers are being overcharged on goods or services they do not have the discretion to avoid. Traditionally, banking services were provided by the public sector or heavily regulated. With privatization, concerns are raised about excessive profiteering.

For companies such as banks, which have a great diversity of individuals and groups as stakeholders, it is important to address a great variety of social responsibility issues and provide related information.

Different sectors have different social responsibility priorities because processes and products are different. Although the banking industry has a different set of contextual circumstances than other industries, some social responsibility activities are not expected to differ greatly. The same cannot be said about other activities, such as those related to environmental impact.

By comparison with other sectors (such as chemicals, paper and pulp, etc.) the financial services sector has lower direct environmental impact.

In addition to disclosing information regarding community involvement, human resources and relations with consumers, banks can report on what they are doing in terms of energy, water and paper use, and to ensure that their lending and investment policies do not facilitate industrial activities which are harmful to the environment. [7] 


\section{Reporting practices of Hungarian banks (GRI database)}

\begin{tabular}{|c|c|c|c|c|c|c|c|c|}
\hline Name & G3 & G3.1 & G4 & $\begin{array}{c}\text { CSR } \\
\text { Report }\end{array}$ & $\begin{array}{l}\text { Sustainability } \\
\text { Report }\end{array}$ & $\begin{array}{l}\text { Annual } \\
\text { report }\end{array}$ & $\begin{array}{c}\text { ISO } \\
26000\end{array}$ & UNGC \\
\hline Budapest Bank & $\mathrm{X}$ & & & $\mathrm{X}$ & $\mathrm{X}$ & & & \\
\hline CIB Bank & $\mathrm{X}$ & & $\mathrm{X}$ & & $\mathrm{X}$ & & & $\mathrm{X}$ \\
\hline $\begin{array}{l}\text { Hungarian National } \\
\text { Bank }\end{array}$ & $X$ & & & & & $X$ & & \\
\hline K\&H Bank & $\mathrm{X}$ & & & & $\mathrm{X}$ & & & \\
\hline MKB Bank & $\mathrm{X}$ & & & & $\mathrm{X}$ & $\mathrm{X}$ & & \\
\hline OTP Bank & $\mathrm{X}$ & $\mathrm{X}$ & $\mathrm{X}$ & $\mathrm{X}$ & $\mathrm{X}$ & & $\mathrm{X}$ & \\
\hline Raiffeisen Bank & $\mathrm{X}$ & & & $\mathrm{X}$ & & & & \\
\hline
\end{tabular}

Table 3. Reporting practice of Hungarian Banks

(Source: made by the author according to GRI database)

Table 3 shows the current state of reporting practices of Hungarian commercial banks and the Hungarian National Bank according to the GRI database.

The list includes the most important companies of all sizes (large, SME, MNE) of financial services sector of Hungary. In the sector we can find almost exclusively banks (except Garantiqa Hitelgarancia, Generali Providencia Biztosító and Pricewaterhouse Coopers Hungary).

Hungarian banks started to provide disclosures in 2007 and have made them since then. In 2007 only two banks, namely CIB Bank and OTP Bank provided reports, both of them were G3 reports. (It means that Hungarian banks left out the phase of G1 and G2 reporting.)

Until 2012 only G3 reports were made but from 2013 newer forms of GRI (G3.1 and G4) reports have been started.

Relating to the number of reports through the years CIB Bank and OTP Bank have made the most disclosures, so these banks can be considered as the most developed banks regarding GRI reporting practices, and the evolution of reporting forms can be seen clearly on their example.

Interestingly there are banks which stopped making GRI reports after some years (such as MKB Bank and Raiffeisen Bank), it would be good to know the reason of this conduct.

K\&H Bank has made Citing-GRI reports recently, it means that these reports make specific reference to or use elements of GRI's Sustainability Reporting Guidelines but do not include a GRI Content Index. 
It can be seen from the database that nowadays the number of disclosures have been decreasing year by year. The year when the most reports were made was 2009 (including reports of Garantiqa Hitelgarancia and Generali Providencia Biztosító that stopped reporting activities since then).

The last year of which the database provides information is 2016, when only four reports were made, by CIB Bank, K\&H Bank and OTP Bank (and Pricewaterhouse Coopers Hungary).

I would note that Hungarian National Bank does not have a great experience of reporting, it only made disclosures three times (between 2013 and 2015) but it did not provide one in 2016.

Most banks provided sustainability reports first and after they started to make CSR reports.

For instance, Hungarian National Bank reports GRI guidelines as part of its annual report.

OTP Bank applies ISO26000 standards while CIB Bank includes UNGC. [9]

\section{Summary}

Although reporting on non-financial performance is not compulsory in most of the countries, there is an increased number of different groups of stakeholders that are demanding this disclosure in order to make informed decisions. Recently, several frameworks and standards have been proposed in relation to how to report on non-financial information but there is still an ongoing need for a systematic, standardized, and unified format of a CSR reporting framework.

An ever-increasing number of organizations want to make their operations sustainable. Profitability should go hand-in-hand with social justice and protecting the environment.

CSR reporting helps organizations set goals, measure performance, and manage change in order to make their operations more sustainable. A sustainability report conveys disclosures on an organization's impacts on the environment, society and the economy. Sustainability reporting makes abstract issues tangible and concrete, thereby assisting in understanding and managing the effects of sustainability developments on the organization's activities and strategy.

\section{References}

[1] Akin, A. - Yilmaz, I. (2016): Drivers of Corporate Social Responsibility Disclosures: Evidence from Turkish Banking Sector. Procedia Economics and Finance 38 (2016) 2-7.

[2] Akmese, H. et al (2016): Corporate Social Responsibility Reporting: A Comparative Analysis of Tourism and Finance Sectors of G8 Countries. Procedia Economics and Finance 39 (2016) 737-745.

[3] Andreescu, N.A. (2015): Analyzing Corporate Social Responsibility Reporting in the European Union. Annals of the University of Oradea, Fascicle of Textiles, Leatherwork.

[4] Ballou, B., Heitger, D., \& Landes, Ch. (2006): The future of corporate sustainability reporting: A rapidly growing assurance opportunity. Journal of Accountancy, 202 (6), 65. 
[5] Bonsón, E. - Bednárová, M. (2015): CSR Reporting Practices of Eurozone companies. Revista de Contabilidad - Spanish Accounting Review, 18 (2) (2015) 182-193.

[6] Bowen, H.R. (1953): Social responsibilities of the businessman. New York: Harper \& Row

[7] Branco, M.C. - Rodrigues, L.L. (2008): Social responsibility disclosure: A study of proxies for the public visibility of Portuguese banks. The British Accounting Review 40 (2008) 161181.

[8] Carroll, A. (1991): Corporate social responsibility evolution of a definitional construct. Business Society, 38(3), 268-295.

[9] GRI database: http://database.globalreporting.org/search. (Downloaded on 4 March 2017)

[10] GRI website: http://globalreporting.org. (Downloaded on 4 March 2017)

[11] KPMG, (2013): The KPMG Survey of Corporate Responsibility Reporting 2013. Amsterdam: KPMG

[12] Marimon, F., Alonso-Almeida, M., \& Rodríguez, M. (2012): The worldwide diffusion of the global reporting initiative: What is the point? Journal of Cleaner Production, 33, 132-144.

[13] Noronha, C., Tou, S., Cynthia, M. I., \& Guan, J. J. (2012): Corporate social responsibility reporting in China: An overview and comparison with major trends. Corporate Social Responsibility and Environmental Management, 20 (1), 29-42.

[14] Outtes-Wanderley, L., Soares, L., Lucian, R., Farache, F., \& de Sousa Filho Milton, J. (2008): CSR information disclosure on the web: A context-based approach analyzing the influence of country of origin and industry sector. Journal of Business Ethics, 82, 369-378.

[15] Rowe, M. (2006): Reputation relationships and risk: A CSR primer for ethics officers. Business and Society Review, 111(4), 441-455.

[16] Tinker, T., \& Niemark, M. (1987): The role of annual reports in gender and class contradictions at general motors. Accounting, Organizations and Society, 12(1), 71-88.

[17] Vartiak, L. (2016): CSR reporting of companies on a global scale. Procedia Economics and Finance 39 (2016) 176-183.

[18] Welford, R. (2004): Corporate social responsibility in Europe, North America and Asia. Journal of Corporate Citizenship, 17, 33-52. 